\title{
PERAN ASISTEN GURU (TEACHING ASSISTANTS) DALAM MAKSIMALISASI PROSES PEMBELAJARAN DI KELAS
}

\author{
Selly Nurina Suraya *
}

\begin{abstract}
A teacher is oblidged against all learning development of the students, in achievement, health, savety and well-being. Class instruction has forbit teacher to do all types of physical harashment, discrimination and careless conduct against the physical-impaired students. Teacher assistant is a person who helps and supports the teacher in classes during the teaching-learning process. In England, he / she is called as teaching assitants, classroom assistants, learnong support assistants, child support assistants or Special Needs Assistants. Both, the teacher and the Special Needs Assistants are oblidged to collaborate to carry out teaching which can serve the students' diversity in each group of the class by applying instruction which is rooted from the students' diversity.
\end{abstract}

Keywords: Special Needs Assistants, Instruction

\begin{abstract}
Abstrak
Seorang guru dituntut bertanggung jawab terhadap muridnya, dalam hal prestasi, kesehatan, keselamatan, dan kesejahteraan siswa. Dalam proses pembelajaran di kelas, guru dilarang melakukan kekerasan / kontak fisik terhadap siswanya, meminimalisir diskriminasi yang ada di kelas, mengupayakan pembimbingan intensif terhadap siswa yang berkebutuhan khusus. Asisten guru adalah seseorang yang mendukung pembelajaran guru di kelas. Di Inggris, asisten guru dikenal dengan istilah teaching assistants, atau classroom assistants, atau learning support assistants, atau child support assistants, atau Special Needs Assistants. Untuk merealisasikan layanan pendidikan yang sesuai dengan kemampuan setiap siswa dari masing-masing kelompoknya di kelas, maka sebaiknya seorang guru menggunakan strategi pembelajaran yang mendasarkan pada keberagaman kemampuan belajar siswa yang berbeda-beda.
\end{abstract}

Kata kunci: Asisten Guru, Proses Pembelajaran

* Selly Nurina Suraya adalah Dosen Prodi PGSD IKIP PGRI Madiun

\section{A. PENDAHULUAN}

Guru adalah ujung tombak keberhasilan pembelajaran. Pembelajaran merupakan proses untuk mengubah siswa yang minus menjadi plus. Pembelajaran yang efektif tidak terlepas dari guru yang profesional. Guru yang profesional bisa 
mengelola aspek-aspek pembelajaran secara efektif. Aspek pembelajaran meliputi, siswa, materi pengajaran, sumber belajar dan media. Pengelolaan aspek pembelajaran yang efektif akan mendorong siswa berpartisipasi secara aktif pada saat proses pembelajaran berlangsung, sehingga mereka tertantang dengan pelajaran yang didiskusikan bersama teman dan guru. Tanggung jawab guru dalam proses pembelajaran tidak hanya sebagai pengajar tetapi juga sebagai pengamat, pendiagnosa, pendidik, fasilitator, konselor, dan pemimpin di dalam kelas.

Sebagai pengamat, guru hendaknya memonitor kebutuhan, keinginan dan kemampuan siswa ketika mereka belajar dan kemajuan yang mereka peroleh dalam konteks pembelajaran. Sebagai pendiagnosa, guru berfungsi untuk membantu siswa dalam mengidentifikasi kesulitan belajar yang mereka alami sekaligus mencarikan solusi yang tepat untuk kesulitan belajar mereka. Sebagai pendidik, guru harus mendidik para siswa tidak hanya pada level kognitif sesuai kualifikasi yang hendak dicapai, tetapi guru juga harus menanamkan nilai-nilai kehidupan (mengekspresikan ide, menghormati orang lain, dan berdisiplin). Sebagai fasilitator, guru hendaknya menstimulasi siswa dengan masalah yang memancing respons siswa secara proaktif. Sebagai konselor, guru membantu para siswa dalam mengeksplor bakat, dan minat mereka. Sebagai pemimpin di dalam kelas, guru harus mengontrol sekelompok siswa khususnya pada sesi diskusi.

Keberagaman kemampuan siswa (diversity learners) dalam suatu kelas terkait dengan perbedaan karakteristik tiap individu siswa. Sebagian diantara mereka mudah menyerap materi, namun sebagian yang lain juga memerlukan waktu yang lebih lama dalam memahami materi pelajaran. Kemampuan menyerap materi yang beragam menyebabkan guru dihadapkan pada dua pilihan yang sulit. Di satu sisi, siswa dengan kapasitas intelektual yang terbatas membutuhkan pengulangan dan pembimbingan intensif namun di saat yang sama siswa yang lain membutuhkan tambahan materi. Gerber mengemukakan bahwa di kelas yang mempunyai keragaman kebutuhan dan keterbatasan sarana prasarana, guru tidak dapat mengoptimalisasikan pembelajaran agar sesuai dengan karakteristik siswa yang beragam (Cook, 2000).

Keberagaman anak di kelas selama ini masih menjadi permasalahan yang langsung dihadapi oleh guru dan belum menjadi bagian dari kebijakan sekolah tentang prosedur pemberian layanan yang harus diberikan. Guru masih bekerja secara sendiri untuk menyelesaikan permasalahan mereka ketika menjumpai anak dengan kemampuan akademik yang beragam. Keterbatasan informasi mengenai apa dan siapa anak-anak dengan kemampuan beragam tersebut menjadi akar permasalahan mengapa penanganan mereka masih minim. Hal ini dipertegas oleh Lopes et al. (2004) yang mengemukakan bahwa guru reguler merasakan banyak beban ketika menghadapi siswa dengan kesulitan belajar yang membutuhkan waktu dan perhatian yang lebih banyak daripada teman-teman yang lain dan tidak menunjukkan hasil yang sesuai harapan. Pengabaian terhadap kebutuhan siswa dengan kesulitan belajar sebagai bagian dari keberagaman di kelas dapat berdampak buruk pada siswa-siswa yang lain karena mereka belajar untuk tidak perduli pada teman yang lemah. Rasa empati yang tidak berkembang pada siswasiswa tersebut dapat berlanjut sampai mereka dewasa.

Bertitik tolak dari uraian di atas, perlu ada sistem pembelajaran yang bisa memfasilitasi perbedaan individu. Seorang guru dituntut bertanggung jawab 
terhadap muridnya, dalam hal prestasi, kesehatan, keselamatan, dan kesejahteraan siswa. Dalam proses pembelajaran di kelas, guru dilarang melakukan kekerasan / kontak fisik terhadap siswanya, meminimalisir diskriminasi yang ada di kelas, mengupayakan pembimbingan intensif terhadap siswa yang berkebutuhan khusus. Tantangan yang dihadapi sekolah negeri di London terutama tuntutan standar nasional yang ditetapkan pemerintah setempat (London Challenge), lingkungan siswa yang multikultural, karakter siswa yang bervariasi, serta harapan akan sosok guru yang ideal. Jika dibandingkan dengan kondisi di Indonesia nampaknya masalah tersebut tidak jauh berbeda.

Tantangan terberat yang dihadapi oleh sekolah-sekolah di Indonesia adalah terbatasnya jumlah guru yang "ideal" dan membeludaknya jumlah murid dengan berbagai ragam karakteristiknya terutama di sekolah-sekolah yang dianggap favorit oleh masyarakat. Akibat serius yang timbul dari hal tersebut adalah seringkali muncul beban kerja yang overload pada guru bersangkutan sehingga fungsi guru sebagai pendidik, fasilitator, pengamat, pendiagnosa, konselor, dan pemimpin di dalam kelas tidak berjalan secara maksimal.

Untuk mengatasi masalah yang terjadi pada pembelajaran di Indonesia, ada satu hal yang bisa diambil dari sistem pembelajaran di London, yaitu adanya asisten guru (teacher assistants). Asisten guru adalah seseorang yang mendukung pembelajaran guru di kelas. Keterlibatan asisten guru mencakup pembimbingan lebih intensif terhadap anak-anak berkebutuhan khusus (special education needs), dimana guru tidak selalu dapat mengakomodasinya dalam kelas normal. Seperti halnya guru, asisten guru juga bertanggung jawab terhadap proses belajar siswa, dan melaporkan kepada guru jika ada permasalahan yang timbul. Dengan adanya asisten guru, guru akan terbantu mengajarnya dalam mengatasi berbagai masalah perbedaan penerimaan materi pelajaran tiap siswanya. Peran-peran asisten guru tersebut sangat penting pula untuk memaksimalkan proses pembelajaran di kelas, sementara guru tetap berkonsentrasi pada pengajaran.

Jika sistem pembelajaran dengan melibatkan asisten guru diterapkan di Indonesia, maka akan bersinergi antara lembaga perguruan tinggi dengan dunia kerja (sekolah tempat mengajar) yang akan digeluti oleh output (mahasiswa calon guru) lembaga pendidikan tinggi. Selain itu juga dapat mengatasi beban kerja guru yng overload sehingga fungsi guru sebagai pengamat pendidik, fasilitator, pengamat, pendiagnosa, konselor dan pemimpin di dalam kelas bisa berjalan dengan baik. Tulisan ini akan mendeskripsikan peran asisten guru (teaching assistants) dalam memaksimalkan proses pembelajaran di kelas dan mendeskripsikan penerapan asisten guru (teaching assistants) di Indonesia.

\section{B. PEMBAHASAN}

\section{Deskripsi Asisten Guru (Teaching Assistants)}

Asisten guru adalah seseorang yang mendukung pembelajaran guru di kelas. Di Inggris, asisten guru dikenal dengan istilah Teaching Assistants, atau Classroom Assistants, atau Learning Support Assistants, atau Child Support Assistants, atau Special Needs Assistants. Asisten guru sering dilibatkan dalam pembelajaran yang diperlukan keluar kelas atau membutuhkan dukungan ekstra seperti kegiatan membaca, berhitung, atau kegiatan investigasi. Keterlibatan asisten guru juga mencakup bekerja dengan anak-anak berkebutuhan khusus 
(special education needs), dimana guru tidak selalu dapat mengakomodasinya dalam kelas normal.

Siswa berkebutuhan khusus bukan hanya siswa yang memiliki kelemahan mental, kecerdasan, dan fisik, melainkan juga termasuk siswa memiliki bakat khusus, dan cerdas. Peraturan hukum di Inggris tentang Special Education Needs bukan hanya merujuk pada murid dengan kelainan fisik dan keterbelakangan mental seperti Down Syndrome melainkan juga murid dengan kesulitan belajar seperti dysleksia dan kelainan dalam hal interaksi-komunikasi seperti anak autis. Sekolah di London sedang berproses menuju sekolah inklusi yang berkewajiban menyediakan layanan khusus untuk anak-anak tersebut baik dalam kegiatan pembelajaran, kegiatan ekstra kurikuler, kunjungan sekolah dan beberapa pengecualian dalam kegiatan sekolah yang tidak memungkinkan.

Seperti halnya guru, asisten guru juga bertanggung jawab terhadap proses belajar siswa, dan melaporkan kepada guru jika ada permasalahan yang timbul. Pengajaran efektif membutuhkan keahlian dan keterampilan dari seorang guru yang berkualifikasi. Namun beberapa kegiatan pengajaran dapat dilakukan oleh staf yang terlatih, asalkan staf tersebut bekerja dalam sistem yang jelas dari kepemimpinan dan pengawasan yang diberikan oleh guru yang berkualifikasi. Staf terlatih tersebut yang dimaksud asisten guru.

\section{Keberagaman Karakteristik Siswa Sekolah}

Menurut Gardner, seorang professor bidang pendidikan di Harvard University, tidak ada anak yang bodoh atau pintar, yang ada adalah anak yang menonjol dalam salah satu atau beberapa jenis kecerdasan. Howard juga menyatakan bahwa kecerdasan bukanlah sesuatu yang bersifat tetap. Namun kecerdasan adalah kumpulan kemampuan atau keterampilan yang dapat ditumbuhkan dan dikembangkan. Menurutnya dalam setiap diri manusia ada delapan macam kecerdasan, yang dikenal sebagai kecerdasan majemuk (multiple intelegence). Delapan macam kecerdasan anak tersebut diantaranya kecerdasan linguistik, kecerdasan logika matematika, kecerdasan intrapersonal, kecerdasan interpersonal, kecerdasan musikal, kecerdasan visual dan spasial, kecerdasan kinestetik jasmani, dan kecerdasan naturalis (Armstrong, 2000).

Kecerdasan linguistik merupakan kemampuan berbahasa. Biasanya anakanak dengan kecerdasan ini lebih suka belajar dengan mendengar. Mereka sering lebih menonjol dalam pelajaran bahasa, membuat puisi, lebih cepat menyerap kosa kata baru atau asing, lebih mampu berbahasa asing dengan baik. Kecerdasan logika matematika merupakan kemampuan yang lebih mahir menggunakan angka-angka, pemecahan masalah secara logis dan matematis. Jenis kecerdasan ini sering menjadi tolak ukur orangtua. Kecerdasan intrapersonal merupakan kemampuan mengenal emosi diri sendiri dan orang lain. Biasanya anak yang mempunyai kecerdasan ini sering menyalurkan pikirannya dengan menulis buku harian, bisa memotivasi diri sendiri, menyukai pemikiran tentang filosofi hidup dan dapat mengembangkan konsep diri dengan baik. Kecerdasan interpersonal merupakan kecerdasan dalam berhubungan dengan orang lain. Biasanya anak dengan kecerdasan ini lebih supel dalam bergaul, mampu menyesuaikan diri dengan lingkungan, suka berempati dan mampu memandang dari sudut pandang orang lain. 
Kecerdasan musikal merupakan sifat seorang anak yang selalu tertarik mendengarkan musik dan memainkan alat musik. Mereka peka terhadap suarasuara dan mampu mengerti nuansa dan emosi yang terkandung dalam sebuah lagu. Anak yang memiliki kecerdasan visual dan spasial biasanya menyukai seni, lukisan dan patung. Mereka memiliki kemampuan membaca arah dengan baik, menikmati permainan puzzle. Mereka juga suka menulis catatan atau menjelaskan pikirannya dengan menggunakan gambar. Anak yang memiliki kecerdasan kinestetik jasmani mampu menggunakan tubuh secara terampil, punya control, ketangkasan, dan keseimbangan gerak. Mereka menyukai pengalaman belajar yang nyata seperti fieldtrip, ingatannya lebih kuat terhadap apa yang pernah dilihat atau dialami.

Kecerdasan naturalis adalah tipe kecerdasan yang dimiliki anak-anak yang menyukai ilmu-ilmu alam, senang melihat tanaman atau hewan, tertarik pada masalah sosial, dan biasanya mampu membaca cuaca dan peduli terhadap lingkungan. Dengan mengetahui delapan kecerdasan majemuk tersebut, beragam cara yang dapat dilakukan orang tua untuk mengembangkan kecerdasan anakanaknya. Tentu saja setiap anak tidak bisa menjadi cerdas di semua bidang, tetapi orangtua dapat membantu anaknya mengoptimalkan semua potensi di setiap area kecerdasannya. Pengoptimalan semua potensi anak dapat dilakukan melalui proses pendidikan. Siswa sebagai individu yang terlibat langsung dalam pembelajaran memiliki karakteristik yang bermacam-macam. Pembelajaran yang ideal harus mampu mewadahi karakteristik individual tersebut.

\section{Hubungan Keberagaman Karakteristik Siswa dengan Pembelajaran}

Untuk merealisasikan layanan pendidikan yang sesuai dengan kemampuan setiap siswa dari masing-masing kelompoknya di kelas, maka sebaiknya seorang guru menggunakan strategi pembelajaran yang mendasarkan pada keberagaman kemampuan belajar siswa yang berbeda-beda. Strategi pembelajaran ini dapat diterapkan dengan efektif melalui perubahan atau penyesuaian antara kemampuan belajar siswa dengan harapan / target, alokasi waktu, penghargaan / hadiah, tugas-tugas / pekerjaan, dan bantuan yang diberikan pada siswa dari masing-masing kelompok yang beragam, meskipun mereka belajar dalam satu kelas dengan tema dan mata pelajaran yang sama.

Contoh keberagaman pelayanan pendidikan yang disesuaikan dengan karakteristik siswa, misalnya target belajar matematika untuk siswa Kelas III SD tentang perkalian, siswa yang cepat belajarnya (high function learners) adalah memahami dan mampu menggunakan perkalian dalam soal cerita dengan analisisnya pada tahapan berpikir abstrak. Untuk siswa yang kemampuan belajarnya rata-rata (average performers) mempelajari perkalian hanya sampai ratusan pada tahap semi konkret, dan untuk siswa yang lambat belajarnya (slow learners) mengenali perkalian baru sampai puluhan dengan tahapan konkrit, serta bagi anak autis mempelajari matematika sampai ratusan dengan lebih banyak memfokuskan pada keunggulan visual thinking-nya (pemahaman konsep melalui pengamatan dengan bantuan gambar, kode, label, simbol atau film).

Demikian pula dengan alokasi waktu, penghargaan / hadiah, tugas-tugas / pekerjaan, dan bantuan yang diberikan juga disesuaikan dengan tahapan perkembangan belajar dari masing-masing kelompok tersebut. Jadi proses layanan pembelajarannya bukan didasarkan pada bentuk layanan sama rata, sama rasa dan 
disampaikan secara klasikal, tetapi diarahkan pada pembelajaran yang lebih demokratis dan proporsional sesuai dengan harapan dan target belajar dari masing-masing kelompok siswa tersebut. Proses belajar siswa tidak dipisahkan berdasarkan kelompok atau dipisahkan dari komunitasnya, melainkan siswa belajar bersama-sama dengan teman sebayanya di dalam kelas regular.

Apabila proses belajar siswa disesuaikan dengan keberagaman dari setiap kelompok, maka semua siswa dalam kelas yang sama dapat mengikuti proses belajar sesuai dengan porsinya masing-masing. Siswa yang belajarnya cepat tidak harus mendapatkan materi pelajaran dan alokasi waktu belajar yang sama dengan teman-teman sebaya pada umumnya (average group) atau sama dengan temannya yang lebih lambat belajarnya atau sama dengan temannya yang autis. Untuk menumbuhkan kepercayaan diri siswa dalam belajarnya, bisa dilakukan dengan pemberian penghargaan / reward. Pemberian reward ini sangat diperlukan oleh semua anak untuk mengembangkan harga dirinya dan identitasnya.

Khususnya bagi siswa yang lambat belajarnya, dengan memperoleh reward pada setiap langkah selama menyelesaikan pekerjaan dan proses belajarnya, maka membuat mereka menjadi lebih percaya diri dalam mengerjakan tugasnya. Dengan kata lain anak harus dihargai apa adanya. Mereka harus merasa aman, bisa mengekspresikan pendapatnya dan sukses dalam belajarnya. Hal ini dapat membantu siswa menikmati belajar dan guru bisa memperkuat rasa senang siswa melalui penciptaan kelas yang lebih menyenangkan. Di dalam kelompok belajarnya, siswa harus selalu didukung, sehingga anak merasa sukses serta senang belajar sesuatu yang baru. Begitu pula bantuan dan bimbingan pada anak yang cerdas pun, tetap perlu diberikan walaupun tidak sebanyak dan seintensif yang diberikan pada anak autis dan anak-anak lain yang lebih lambat belajarnya. Pada anak-anak autis dan yang lambat belajarnya membutuhkan bimbingan pada setiap tahapan belajarnya. Jadi, apabila strategi dan atmosfir proses belajar seperti telah dijelaskan tersebut dapat direalisasikan dengan optimal, maka dapat mengantarkan semua siswa untuk mencapai proses belajar yang menyenangkan.

\section{Peranan Asisten Guru dalam Memaksimalkan Proses Pembelajaran}

Peran asisten guru adalah membantu guru dalam mengembangkan kemampuan berpikir siswa terhadap materi pelajaran yang diterimanya. Beberapa peran asisten guru adalah: (1) mempersiapkan peralatan dan bahan untuk mengajar dan membersihkan setelahnya; (2) membimbing satu persatu atau secara berkelompok siswa yang memerlukan bantuan dalam memahami pelajaran; (3) membantu siswa yang cedera saat mengikuti pelajaran olahraga; dan (4) mengumpulkan pajangan karya anak-anak.

Peran-peran asisten guru diatas sangat penting untuk memaksimalkan proses pembelajaran di kelas, sementara guru tetap berkonsentrasi pada pengajaran. Keberagaman kemampuan siswa dalam memahami materi tidak menjadi masalah bagi guru jika pengajarannya dibantu asisten guru dalam membimbing siswanya belajar. Dengan bantuan asisten guru, fungsi guru sebagai fasilitator, pengamat, pendiagnosa, konselor dan pemimpin di dalam kelas akan berjalan secara maksimal. Asisten guru yang berpengalaman dan terlatih khusus dapat diharapkan untuk mengawasi kelas, jika ada guru yang cuti sakit atau sedang ada tugas. 
Di semua sekolah di London, misalnya di Horsenden Primary School, London, ada asisten guru yang membantu guru dalam mengajar. Anak berkebutuhan khusus bergaul satu sekolah dengan anak normal. Sama halnya dengan di Torriano Junior School, London setiap kelas diampu oleh seorang guru dan dibantu oleh satu orang atau dua orang asisten guru. Tugas asisten adalah membantu siswa yang berkebutuhan khusus. Di samping itu, juga disediakan paket-paket pembelajaran khusus bagi siswa berkebutuhan khusus.

\section{Proses Rekruitmen Asisten Guru}

Seseorang untuk menjadi asisten guru, dalam sistem pendidikan di London, mereka harus melalui tahapan proses pendidikan. Proses rekruitmen asisten guru di sekolah dimulai saat mahasiswa (calon guru) melaksanakan praktik mengajar, istilahnya School Experience Placement (SEP). Praktik mengajar merupakan media bagi mahasiswa untuk mengaplikasikan dasar profesi pendidikannya. Praktik mengajarnya diaplikasikan dalam bentuk observasi pembelajaran, praktik mengajar dan kegiatan edukasional lainnya di lembaga sekolah. Melalui praktik mengajar ini, mahasiswa akan dibimbing oleh mentor (guru pamong) lalu dievaluasi. Praktik mengajar mahasiswa di sekolah dilakukan secara berkala sampai mereka akan lulus program pendidikannya.

Keuntungan yang didapat setelah melakukan SEP, mahasiswa akan mempunyai pengalaman menjadi seorang guru yang profesional, memiliki kesempatan untuk menerapkan ilmu mengajar yang didapat di perguruan tinggi, mendapat bimbingan dari guru pamong (mentor) atau dosen pembimbing praktik mengajar. Setelah melaksanakan SEP, mahasiswa akan menempuh ujian untuk mencapai standart profesional guru yang ditetapkan-QTS (Qualified Teacher Status). Penilaian SEP mahasiswa didasarkan pada school-based learning dan practical teaching. Penentuan kelulusan mahasiswa dibuat dalam tiga tingkatan, yaitu: (1) Outstanding Student; (2) Good Student; dan (3) Satisfactory Student. Mahasiswa yang nilainya di bawah kriteria satisfactory tidak diijinkan untuk mengikuti Qualified Teacher Status (QTS). Professional Standards for Qualified Status dapat diunduh diwebsite: www.tda.gov.uk/standards.

Istilah SEP (school experience placement) di London sama dengan PPL (Praktik Pengalaman Lapangan) mahasiswa di perguruan tinggi di Indonesia. Jika pelaksanaan PPL diadaptasi dari SEP di London, maka kualitas lulusan mahasiswa di Indonesia akan semakin baik dan berkompeten di bidang pendidikan dan pengajaran. Penempatan asisten guru diperlukan kerjasama yang baik antara LPTK dengan sekolah yang ditunjuk untuk praktik mengajar. Penerimaan calon guru di sekolah akan lebih utama, jika calon guru tersebut telah menjadi asisten guru terlebih dahulu. Banyak sekolah yang dapat memperkerjakan asisten guru dengan spesialisasi bidang, seperti Bahasa Indonesia, Matematika, Musik, Sains, Pendidikan Anak Berkebutuhan Khusus, tergantung latar belakang pendidikannya.

\section{PENUTUP}

\section{Kesimpulan}

Asisten guru adalah seseorang yang mendukung pembelajaran guru di kelas. Peran asisten guru adalah membantu guru dalam mengembangkan kemampuan berpikir siswa yang beragam terhadap materi pelajaran yang 
diterimanya. Peran-peran asisten guru sangat penting untuk memaksimalkan proses pembelajaran di kelas, sementara guru tetap berkonsentrasi pada pengajaran. Dengan bantuan asisten guru, fungsi guru sebagai fasilitator, pengamat, pendiagnosa, konselor dan pemimpin di dalam kelas akan berjalan secara maksimal. Penempatan asisten guru diperlukan kerjasama yang baik antara LPTK dengan sekolah yang ditunjuk untuk praktik mengajar. Penerimaan calon guru di sekolah akan lebih utama, jika calon guru tersebut telah menjadi asisten guru terlebih dahulu.

\section{Saran}

Berdasarkan pembahasan di atas, ada beberapa saran yang disampaikan guna meningkatkan kualitas pendidikan berkaitan dengan memaksimalkan kegiatan pembelajaran di sekolah, yaitu:

a. Ada asisten guru yang membantu guru utama untuk melayani kebutuhan siswa dengan karakter yang beragam di setiap sekolah;

b. Lembaga pendidikan tinggi perlu mengoptimalkan kemitraan dengan sekolah dalam bentuk pemberian kesempatan observasi, pendampingan, mentoring, dan praktik pembelajaran dalam waktu yang cukup panjang, sehingga dapat memberikan kesempatan mahasiswa untuk memperoleh pengetahuan dan pengalaman praktis tentang mengajar;

c. Kegiatan praktik mengajar di sekolah (Praktik Pengalaman Lapangan / PPL) sebaiknya diperpanjang waktunya dengan memberikan kesempatan mahasiswa calon guru untuk magang di sekolah sebagai asisten guru. Sehingga pada akhir program, mahasiswa memiliki rasa percaya diri dan kemampuan beradaptasi-bersosialisasi dengan berbagai lingkungan sekolah;

d. Setiap lingkungan pendidikan hendaknya menciptakan suasana belajar yang kondusif, misalnya menjalin kerjasama yang baik antara guru, siswa, beserta staf sekolah lainnya sebagai tim yang besar dan memiliki visi yang sama agar tujuan bersama tercapai. 


\section{DAFTAR RUJUKAN}

Armstrong, T. 2000. Multiple Intelegences In The Classroom. Alexandria, Virginia: Association for Supervision and Curriculum Development.

Cook B.G, et al. 2000. Teacher's Attitudes Toward their Included Students with Disabilities Exceptional Children Fall. ProQuest Education Journals, 1(1): 115.

Cooper, H. M., dan Tom, D. Y. H. 1984. Teacher Expectation Research: A Review with Implications for Classroom. Elementary School Journal. 85(1): 77-89, (Online), (http://www.nwrel.org/scpd/re-engineering/rycu/ ReferenceDetails.asp?RefID=188, diakses 6 April 2010).

Sumarno, A. 2011. Strategi Pembelajaran yang Mendasarkan pada Keberagaman (Online). (http://www.elearning.unesa.ac.id, diakses 10 Maret 2012).

www.tda.gov.uk/standards. Professional Standards for Qualified Teacher Status.

www.teaching-assistants.co.uk/Teaching, Assistants \& Classroom Assistants. 